Jurnal Ekonomi dan Bisnis Indonesia

JEBI

JEBI Vol. 1, No. 2, pp. 8-17

Copyrigt $\odot 2016$ Fakultas Ekonomi dan Bisnis UTS

Jurnal Ekonomi dan Bisnis Indonesia

\title{
CIRCULAR CUMULATIVE CAUSATION THEORY DAN IMPLIKASINYA TERHADAP KEBOCORAN EKONOMI WILAYAH: STUDI KASUS AGRIBISNIS TEMBAKAU VIRGINIA DI PULAU LOMBOK
}

\author{
Circular Cumulative Causation Theory and its Impact on Regional Economic Leakages: Case \\ Study of Virginia Tobacco Agribusiness in Lombok Island
}

\author{
Muhammad Nurjihadi ${ }^{1}$ \\ 'Program Studi Ekonomi Pembangunan, Fakultas Ekonomi dan Bisnis Universitas Teknologi Sumbawa \\ *) e-mail: mnur.jihadi@gmail.com
}

Tanggal Diterima: 10 September 2016

\begin{abstract}
Circular cumulative causation theory (C3 theory) stated that in the free market based economy, the contribution of backwash effect is higher than the contribution of spread effect on regional economic development which lead to better condition in developed regions while the underdeveloped regions remain undeveloped. Backwash effect could be a source of regional economic leakages since the absence of added value process in the underdeveloped regions. The aims of this research are to describe the relationship between circular cumulative causation theory and regional economic leakages phenomenon on virginia tobacco agribusiness in Lombok Island. This research using mix method between both quantitative and qualitative method with descriptive approach. Quantitative analysis conducted by developing a specific model which developed from Tarigan concept about regional income. The result of the research revealed that $C 3$ theory is also occurs on virginia tobacco agribusiness in Lombok Island which shown by the big number of regional economic leakages as one of a form of backwash effect.
\end{abstract}

Keywords: C3 theory, Economic leakages, Backwash effect, Tobacco, Lombok

\section{ABSTRAK}

Circular cumulative causation theory (teori C3) menjelaskan bahwa dalam ekonomi berbasis pasar, backwash effect lebih besar dari pada spread effect dalam proses pembangunan wilayah yang menyebabkan wilayah maju semakin maju sementara wilayah terbelakang tetap tertinggal. Besarnya backwash effect dapat mendorong terjadinya kebocoran ekonomi wilayah akibat tidak adanya proses pengolahan hasil atau penciptaan nilai tambah di wilayah terbelakang. Penelitian ini bertujuan untuk mengungkap dan mendeskripsikan hubungan antara teori circular cumulative causation dengan fenomene kebocoran ekonomi wilayah dalam agribisnis tembakau virginia di Pulau Lombok. Penelitian ini menggunakan metode campuran (mix method) antara metode kuantitatif dan metode kualitatif dengan pendekatan deskriptif. Analisis data kuantitatif dilakukan dengan membangun formula secara mandiri yang dikembangkan dari konsep pendapatan wilayah menurut Tarigan. Hasil penelitian menunjukkan bahwa tesis Gunar Myrdal mengenai Circular Cumulative Causation Theory terjadi dalam agribisnis tembakau virginia Lombok yang ditunjukkan dengan besarnya nilai kebocoran ekonomi wilayah sebagai salah satu bentuk backwash effect.

Kata Kunci: Teori C3, Kebocoran ekonomi, Backwash effect, Tembakau, Lombok

\section{Pendahuluan}

Circular Cumulative Causation theory atau teori sebab akibat kumulatif menekankan pada hipotesis bahwa penerapan sistem ekonomi pasar dengan peran pemerintah yang minim dalam suatu perekonomian dapat menyebabkan ketimpangan wilayah. Hal ini terjadi karena dalam ekonomi pasar, para pelaku ekonomi sepenuhnya digerakkan oleh motif laba. Oleh karenanya para investor akan memilih untuk berinvestasi di wilayah yang memungkinkan mereka untuk mendapat laba tinggi, yakni wilayah dengan infrastruktur memadai, ketersidaan Sumber Daya Manusia (SDM) yang produktif dengan tingkat upah relatif rendah, ketersediaan pasar (konsumen) yang tinggi, masyarakat yang berfikir terbuka dan modern, serta biaya transaksi dan transportasi relatif rendah (Myrdal, 1957). Rustiadi et al (2011) dan Tarigan (2002) mengasosiasikan wilayah dengan ciri seperti itu sebagai wilayah maju. Sebaliknya, wilayah terbelakang memiliki ciri bertolak belakang seperti infrastruktur tidak memadai, masyarakat yang konservatif dan tidak produktif, pasar potensial rendah, serta akses jaringan pengangkutan yang tidak efisien. Hal itu membuat aliran modal ke dalam wilayah terbelakang menjadi sangat minim sehingga mereka biasanya mengekspor hasil alam dalam keadaan mentah karena tidak tersedianya teknologi dan modal untuk mengolah hasil alam tersebut didalam wilayahnya. Dengan 
demikian maka wilayah maju semakin maju, sementara wilayah terbelakang kian tertinggal.

Teori pembangunan klasik dan neoklasik sebenarnya memiliki pandangan berbeda dengan circular cumulative causation theory. Teori klasik itu meyakini bahwa dalam jangka panjang, mekanisme pasar dapat menciptakan struktur perkembangan wilayah yang seimbang. Hal itu dapat terjadi karena adanya efek menetes kebawah (trickle down effect) dari berkembangnya industri di pusat pertumbuhan (growth pole) ke wilayah terbelakang (Rustiadi et al, 2011). Sementara Myrdal (1957) dalam Cumulative causation theory menyatakan bahwa trickle down effect yang terjadi dalam mekanisme pasar sangat sedikit jika dibandingkan dengan efek pencucian balik (backwash effect) yang ditimbulkannya. Efek difusi berupa trickle down itu disebut efek sebar (spread effect) dalam terminologi Myrdal (Capello, 2007). Backwash effect menurut Myrdal adalah segala perubahan yang bersifat merugikan dari ekspansi ekonomi suatu wilayah karena sebab-sebab diluar wilayah itu, baik yang bersifat ekonomi maupun non ekonomi. Sementara itu spread effect didefinisikan sebagai dampak positif dari proses pembangunan yang menyebar secara sentrifugal dari pusat pengembangan ekonomi ke wilayahwilayah lainnya. Lebih besarnya backwash effect dari pada spread effect menyebabkan terjadinya kebocoran ekonomi wilayah sehingga keseimbangan pembangunan jangka panjang sebagaimana dikatakan dalam teori klasik tidak dapat terjadi.

Kebocoran ekonomi (economic leakages) mengacu pada kondisi hilangnya kesempatan masyarakat di suatu wilayah untuk memperoleh pendapatan akibat adanya aliran nilai tambah keluar wilayah. Sementara itu Bendavid (1991) menyebut kebocoran sebagai tipe pengeluaran yang tidak meningkatkan tambahan pendapatan domestik seperti pada pengeluaran pembelian barang-barang impor, pembelian di luar wilayah, pengeluaran pajak, tabungan, dan sejenisnya yang tidak meningkatkan arus pendapatan bagi masyarakat dan wilayah tersebut. Banyaknya impor dan pembelian yang dilakukan masyarakat suatu wilayah di luar wilayahnya menunjukkan rendahnya aktifitas penciptaan nilai tambah (produksi olahan) di wilayah tersebut.

Tembakau merupakan salah satu komoditas bernilai ekonomi tinggi yang berkembang sebagai respon dari menguatnya industri rokok. Sebagai bahan baku utama pembuatan rokok yang dikonsumsi di seluruh dunia, tembakau berperan penting dalam menopang perekonomian banyak negara sejak abad ke 17. Tembakau pertama kali diusahakan di Indonesia melalui kebijakan tanam paksa yang diterapkan pemerintah kolonial Belanda pada abad ke 18. Saat itu, komoditas tembakau merupakan salah satu komoditas ekspor utama pemerintah kolonial dari wilayah Hindia Belanda.

Pasca berakhirnya kebijakan tanam paksa, masyarakat pedesaan Pulau Jawa tetap mengusahakan tanaman tembakau secara turun-temurun mengingat tingginya nilai ekonomi tembakau di pasar dunia. Pengusahaan komoditas tembakau itu bahkan tetap berlanjut pasca proklamasi kemerdekaan Republik Indonesia. Dalam perkembangannya, komoditas tembakau tidak hanya diusahakan di wilayah Pulau Jawa, tapi juga menyebar ke berbagai wilayah di Indonesia. Data yang dipublikasikan oleh Pusat Data dan Sistem Informasi Kementerian Pertanian (Pusdatin Kementan) menunjukkan bahwa ada tiga provinsi penghasil utama tembakau di
Indonesia, yakni Jawa Timur, Jawa Tengah dan Nusa Tenggara Barat (NTB). Pada tahun 2013 produksi tembakau Provinsi NTB mencapai 61.301 ton yang setara dengan $23,6 \%$ total produksi nasional. Jumlah itu merupakan kedua terbanyak setelah Provinsi Jawa Timur yang mampu memproduksi 133.678 ton atau $51,4 \%$ dari total produksi nasional pada tahun yang sama. Adapun Jawa Tengah memproduksi 44.224 ton atau setara dengan $17 \%$ produksi nasional (Pusdatin Kementan, 2014).

Penyebaran tanaman tembakau di Provinsi NTB sepenuhnya ada di Pulau Lombok. Bagi sebagian masyarakat Pulau Lombok, tembakau merupakan primadona, jalan hidup (way of life), sumber pendapatan utama, dan bahkan sudah menjelma menjadi tradisi ekonomi yang sulit dihentikan. Masyarakat bahkan menyebut komoditas tembakau sebagai "emas hijau" karena tingginya nilai ekonomi komoditas tembakau dibanding dengan komoditas pertanian lainnya. Meski demikian Nurjihadi (2016) menjelaskan bahwa telah terjadi lingkaran setan kemiskinan di wilayah Pedesaan Pulau Lombok yang mengusahakan agribisnis tembakau. Hal ini terjadi karena rendahnya posisi tawar petani dalam perdagangan komoditas tembakau, serta terjebaknya petani dalam pola kemitraan dengan perusahaan pengepul tembakau yang cenderung eksploitatif.

Rustiadi (2011) menjelaskan bahwa pendapatan wilayah secara sederhana dapat dipahami sebagai total pendapatan masyarakat di wilayah tertentu. Ukuran yang paling umum digunakan untuk mengukur pendapatan suatu wilayah adalah Produk Domestik Regional Bruto (PDRB). Meski demikian PDRB mengukur pendapatan wilayah secara agregat dan tidak menjelaskan pendapatan masyarakat secara sektoral atau subssektoral seperti pendapatan wilayah dari pengusahaan komoditas tertentu. Oleh karenanya PDRB tidak dapat memberikan gambaran pendapatan wilayah Pulau Lombok dari berkembangnya agribisnis tembakau Virginia di wilayah tersebut. Dalam penelitian ini, pendapatan wilayah Pulau Lombok dari agribisnis tembakau Virginia dikembangkan dari gagasan Tarigan (2002) yang menjelaskan bahwa pendapatan suatu wilayah dari aktifitas usaha tertentu dapat dilihat dari total upah atau gaji yang diterima seluruh pekerja dan buruh di wilayah tersebut, total keuntungan usaha, sewa lahan, bunga pinjaman, penyusutan, dan pajak serta retribusi ke pemerintah daerah.

Pulau Lombok sebagai salah satu penghasil utama tembakau di Indonesia seharusnya mendapatkan manfaat ekonomi yang besar dari komoditas bernilai tinggi tersebut. Namun penelitian yang dilakukan oleh Tobacco Control Support Center - Ikatan Ahli Kesehatan Masyarakat Indonesia (TCSC - IAKMI) mengungkap bahwa upah rata-rata petani tembakau secara nasional pada tahun 2005 adalah $\mathrm{Rp} 413.374$ per bulan atau setara dengan $47 \%$ rata-rata upah nasional yang mencapai Rp 883.693 (TCSC IAKMI, 2008). Sementara itu perusahaan rokok yang merupakan tujuan akhir dari rantai supply tembakau selalu mampu menjaga tingkat keuntungan yang besar. Pada tahun 2015, total laba kotor HM.Sampoerna sebagai perusahaan rokok dengan market share terbesar di Indonesia adalah Rp 14,33 Trilliun, pada tahun 2016 ini, laba kotor Sampoerna diperkirakan mencapai Rp 15,04 Trilliun (Bisnis.com, 2016). Meski Pulau Lombok menjadi salah satu penghasil utama tembakau di Indonesia, tetapi industri pengolahan rokok tidak tersedia di Pulau Lombok, melainkan tersebar di berbagai wilayah di Pulau Jawa. Kondisi ini merupakan bukti awal dari berlakunya teori circular 
cumulative causation yang dicetuskan Myrdal. Selain itu, paradoks keuntungan antara petani tembakau dan perusahaan rokok sebagaimana disebutkan diatas merupakan salah satu indikasi adanya kebocoran ekonomi dalam agribisnis tembakau Virginia di Pulau Lombok. Penelitian ini bertujuan untuk mengungkap dan mendeskripsikan hubungan antara teori circular cumulative causation dengan fenomene kebocoran ekonomi wilayah dalam agribisnis tembakau virginia di Pulau Lombok.

\section{Metode Penelitian}

Penelitian ini menggunakan metode campuran (mix method) antara metode kuantitatif dan metode kualitatif dengan pendekatan deskriptif. Data dalam penelitian ini berbentuk data primer dan data sekunder. Data primer didapatkan langsung dari responden melalui wawancara, wawancara mendalam, Focus Group Discussion (FGD), dan penelitian berperan serta. Selain itu data primer juga didapatkan dari survey pasar harga eceran rokok sebagai produk akhir dari komoditas tembakau. Sedangkan data sekunder didapatkan dari institusi-institusi terkait seperti Dinas Perkebunan, BPS dan Perusahaan pengepul tembakau. Penelitian ini dilakukan pada bulan Januari 2013 sampai dengan April 2013 Penelitian dipusatkan di dua Kabupaten penghasil utama tembakau di Pulau Lombok yakni Kabupaten Lombok Timur dan Kabupaten Lombok Tengah. Sampel penelitian ditetapkan dengan cara simple random sampling, sementara wilayah sampel ditetapkan secara purposive. Kabupaten Lombok Timur diwakili oleh 6 Kecamatan dengan masingmasing kecamatan diwakili oleh 1 sampai 2 desa. Sementara itu Kabupaten Lombok Tengah diwakili oleh 2 kecamatan dengan masing-masing kecamatan dipilih 1 desa sampel. Pemilihan wilayah sampel tersebut didasarkan pada luas areal lahan, jumlah produksi dan jumlah petani di masing-masing wilayah. Wilayah yang dipilih secara purposive memiliki keunggulan dalam luas lahan, jumlah produksi maupun jumlah petani dibanding wilayah lainnya. Adapun jumlah total responden adalah 100 orang yang tersebar di 10 desa, 8 kecamatan dan 2 kabupaten di Pulau Lombok. Sementara itu wawancara mendalam dilakukan terhadap informan kunci (key informant) yang dipilih secara purposive. Adapun informan kunci yang terpilih dalam penelitian ini adalah Manager PT. Djarum Lombok, Manager PT AOI Lombok, Ketua Himpunan Petani Tembakau Lombok (Hipetal), Ketua Asosiasi Petani Tembakau Indonesia (APTI) Wilayah Lombok, dan Pimpinan Dinas Perkebunan Provinsi NTB. Sementara itu FGD dilakukan sebanyak 3 kali dengan beberapa kelompok tani di wilayah sampel yang berbeda dan 1 kali dengan kelompok pakar yang merupakan informan kunci dan pengambil kebijakan pertembakauan di Provinsi NTB.

Analisis data dalam penelitian ini dilakukan secara kuantitatif dengan membangun formula secara mandiri yang dikembangkan dari konsep pendapatan wilayah menurut Tarigan. Hal ini dilakukan karena belum ditemukan metode yang tetap dan teruji untuk mengukur kebocoran ekonomi wilayah. Pada umumnya kebocoran ekonomi itu diukur dengan menggunakan analisis Input-Output, namun tidak tersedianya data Input-Output yang terbaru membuat metode itu tidak memungkinkan untuk digunakan. Untuk menghitung kebocoran ekonomi pada agribisnis tembakau dalam penelitian ini diperlukan data mengenai total nilai ekonomi tembakau setelah diolah menjadi rokok dan data total pendapatan wilayah yang didapatkan masyarakat Pulau
Lombok dari agribisnis tembakau. Nilai ekonomi tembakau dihitung dengan pendekatan harga jual eceran rokok menggunakan rumus berikut:

$\begin{array}{ll}\mathrm{TEV} & =(\mathrm{P}-\mathrm{C}-\mathrm{KF}-[\mathrm{Pc}-\mathrm{T}]-\pi \mathrm{p}-\mathrm{o})(\mathrm{V} \%)(\mathrm{R}) \ldots . .(1) \\ \mathrm{V} \% & =(0,5 \mathrm{gr} / \mathrm{BR}) 100 \% \ldots \ldots \ldots \ldots \ldots \ldots \ldots \ldots \ldots \ldots \ldots \ldots \ldots \ldots \ldots \ldots \ldots \ldots \ldots \ldots \ldots \ldots \ldots \ldots \ldots \ldots \ldots \ldots \ldots \ldots \ldots \ldots \ldots \\ \mathrm{R} & =\mathrm{TPa}(\mathrm{gr}) / 0,5 \mathrm{gr} \ldots \ldots \ldots \ldots \ldots \ldots \ldots \ldots \ldots \ldots\end{array}$

dimana,

$\mathrm{TEV}=$ Tobacco economic value, nilai ekonomi tembakau virginia Lombok

$\mathrm{P} \quad=$ Price, harga eceran per batang rokok

$\mathrm{C}=$ Biaya cukai hasil tembakau

$\mathrm{KF}=$ Kertas dan Filter rokok serta kemasannya

$[\mathrm{Pc}-\mathrm{T}]=$ Production cost minus tobacco, perkiraan biaya produksi per batang rokok untuk keperluan selain tembakau dan penyedap rasa lainnya seperti cengkeh dan saus.

$\pi \mathrm{p} \quad=$ Keuntungan pedagang pengecer

o = other, biaya lai-lain seperti transportasi, dan sebagainya

$\mathrm{V} \%=$ Perkiraan prosentase penggunaan tembakau virginia dalam satu batang rokok

$\mathrm{R}=$ Jumlah total batang rokok yang mengandung tembakau virginia Lombok

$\mathrm{TPa}=$ Agregat total Production, total produksi tembakau agregat

$0,5 \mathrm{gr}=$ Merupakan rata-rata kandungan atau komposisi tembakau virginia dalam satu batang rokok menurut keterangan informan kunci (pimpinan perusahaan).

Nilai ekonomi tembakau virginia Lombok secara sederhana dapat diartikan sebagai nilai jual tembakau virginia Lombok setelah diolah dan berubah bentuk menjadi produk rokok, dengan kata lain seberapa besar kemampuan agribisnis tembakau Lombok itu dalam menciptakan (creating) nilai tambah. Adapun rokok yang dijadikan sampel dalam penelitian ini diambil dari berbagai merk dan perusahaan yang berbeda. Nilai ekonomi dari tembakau virginia Lombok perlu diketahui sebagai dasar untuk menghitung total kebocoran ekonomi wilayah dalam agribisnis tembakau virginia Lombok. Kebocoran ekonomi itu akan dihitung dari selisih antara nilai ekonomi tembakau virginia Lombok dan total pendapatan wilayah Pulau Lombok dari agribisnis tembakau virginia. Pendapatan wilayah Pulau Lombok dari agribisnis tembakau virginia diperoleh dari pendapatan masyarakat (petani, buruh tani, tuan tanah, rentenir, dll) maupun penerimaan pemerintah daerah melalui pajak, cukai dan retribusi. Secara matematis total pendapatan wilayah pada agribisnis tembakau Virginia di Pulau Lombok ini dihitung dengan rumus:

$\mathrm{RIt}=\mathrm{RI} \pi+\mathrm{RIL}+\mathrm{RILR}+\mathrm{RIi}+\mathrm{RIIr}+\mathrm{RIRo}+\mathrm{GI}$

dimana,

RIt =Regional income in tobacco agribusiness, atau pendapatan wilayah dari agribisnis tembakau virginia Lombok

$\mathrm{RI} \pi=$ Regional income from farmer profit, pendapatan wilayah dari laba usahatani petani tembakau

RIL = Regional income from Labor wage, pendapatan wilayah dari upah buruh 
$\mathrm{RILR}=$ Regional income from Land rent, pendapatan wilayah dari biaya sewa lahan yang diterima tuan tanah

$\mathrm{RIi}=$ Regional income from interest, pendapatan wilayah dari total bunga pinjaman dan penyusutan

RIIr = Regional Income from irrigation cost, pendapatan wilayah dari total biaya irigasi yang dibayar petani

$\mathrm{RIRo}=$ Regional income from oven renovation, pendapatan wilayah dari biaya renovasi oven

GI = Government income, pendapatan pemerintah daerah dari agribisnis tembakau

Sisi kiri dalam persamaan (4) diatas merupakan variabel tak bebas, sedangkan sisi kanan persamaan merupakan variabel bebas. Sebelum menghitung total pendapatan wilayah dari agribisnis tembakau virginia Lombok itu, terlebih dahulu perlu dicari nilai dari masing-masing variabel bebas dengan rumus-rumus berikut:

$\mathrm{RI} \pi=\pi \mathrm{x} \mathrm{TF}$

dimana,

$\mathrm{RI} \pi=$ Regional income from farmers profit, pendapatan wilayah dari laba petani tembakau virginia Lombok

$\pi \quad=$ farmer profit, keuntungan (laba) usahatani petani per hektar tanaman tembakau virginia

$\mathrm{TF}=$ Total field, total luas areal pertanaman tembakau di Pulau Lombok

$\mathrm{RIL}=\mathrm{LC} \times \mathrm{TF}$

dimana,

RIL = Regional income from labor wage, pendapatan wilayah dari upah buruh tani tembakau virginia lombok

LC = Labor cost, total kebutuhan biaya tenaga kerja dalam setiap satu hektar pertanaman tembakau virginia Lombok

$\mathrm{TF}=$ Total field , total luas areal pertanaman tembakau di Pulau Lombok

RILR $=$ LR $\times$ TF

dimana,

RILR = Regional income from land rent, pendapatan wilayah dari biaya sewa lahan untuk usahatani tembakau

LR =Land rent, biaya sewa lahan per hektar tanaman tembakau virginia lombok

TF $=$ Total field, total luas areal pertanaman tembakau di Pulau Lombok

$\mathrm{RIi}=(\mathrm{iLR}+\mathrm{iLP}+\mathrm{iIr}+\mathrm{iSs}+\mathrm{iRo})(\mathrm{TF})$

dimana,
RIi =Regional income from interest, pendapatan wilayah dari bunga pinjaman dan nilai penyusutan dalam usahatani tembakau virginia Lombok

iLR = Bunga biaya sewa lahan per hektar

iLP = Bunga biaya upah tenaga kerja (buruh) per hektar

iIr = Bunga biaya irigasi per hektar

iSs = Bunga nilai penyusutan per hektar

iRo = Bunga biaya renovasi oven per hektar

$\mathrm{TF}=$ Total field, total luas areal pertanaman tembakau di Pulau Lombok

$\mathrm{RIIr}=\mathrm{Ir} \mathrm{x}$ TF

dimana,

RIIr = Regional income from irrigation, pedapatan wilayah dari biaya yang dikeluarkan untuk keperluan pengairan dalam usahatani tembakau virginia lombok

Ir = Irrigation, total biaya irigasi per hektar tanaman tembakau

$\mathrm{TF}=$ Total field, total luas areal pertanaman tembakau di Pulau Lombok

RIRo $=$ Ro $x$ TF

dimana,

RIRo $=$ Regional income from oven renovation, pendapatan wilayah dari biaya renovasi oven oleh petani

Ro = Biaya renovasi oven untuk kebutuhan pengovenan tembakau hasil produksi dalam satu hektar pertanaman

$\mathrm{TF}=$ Total field, total luas areal pertanaman tembakau di Pulau Lombok

GIt $=$ RIGS + RIGC

dimana,

GIt = Government income from tobacco agribusiness, besarnya pendapatan pemerintah daerah karena adanya usaha agribisnis tembakau virginia Lombok

RIGS=Pendapatan wilayah dari penerimaan pemerintah dalam bentuk sumbangan sukarela (retribusi)

RIGC $=$ Pendapatan wilayah dari penerimaan pemerintah daerah dalam bentuk Dana Bagi Hasil Cukai tembakau (DBHCT).

Untuk mengetahui nilai dari variabel bebas pada persamaan (5), (6), (7), (8), (9), (10), dan (11), diperlukan data primer hasil analisis usaha tani tembakau Virginia Lombok untuk satu hektar pertanaman. Selain itu dibutuhkan juga data sekunder mengenai luas areal pertanaman tembakau di Pulau Lombok. 
Setelah mengetahui nilai ekonomi dari tembakau Virginia Lombok dengan menggunakan persamaan (1) dan nilai pendapatan wilayah Pulau Lombok dari agribisnis tembakau dengan menggunakan persamaan (4), maka dapat dihitung total kebocoran ekonomi wilayah dengan rumus berikut:

$\mathrm{EL}=\mathrm{TEV}-\mathrm{RIt}$

dimana,

EL =Economic Leakages (kebocoran ekonomi) dalam agribisnis tembakau virginia Lombok

TEV =Total of Economic Value, total nilai ekonomi tembakau virginia Lombok setelah diolah menjadi rokok.

RIt =Regional income from tobacco, total pendapatan wilayah pulau Lombok dari agribisnis tembakau virginia.

\section{Agribisnis Tembakau Virginia Lombok dan Circular Cumulative Causation Theory}

Agribisnis tembakau virginia mulai diusahakan di Pulau Lombok sejak tahun 1969 bersamaan dengan masuknya PT. Faroka Tbk. Langkah PT. Faroka ini kemudian diikuti oleh PT. British American Tobacco (BAT) Indonesia pada tahun 1971 serta PTP.XXVII dan NV GIEB pada tahun 1974. Memperhatikan keberhasilan rintisan usahatani tembakau virginia di Pulau Lombok, maka secara bertahap hadir perusahaan-perusahaan lain untuk turut mengembangkan tembakau virginia. Perusahaan - perusahaan yang dimaksud adalah PT. Djarum pada tahun 1980, PT. Anugrah Alam Abadi, PT. Mangli Jaya Raya, PT. Cakrawala pada tahun 1987 serta PT. Tresno Bentoel pada tahun 1989. Langkah ini disusul oleh PT. Trisno Adi, PT. HM. Sampoerna, PT. Sadhana Arifnusa dan PT. Gelora Djaja dan UD. Nyoto Permadi tahun 1999. (Disbun NTB, 2002). Sejak awal, kehadiran perusahaan-perusahaan tersebut di Pulau Lombok ditujukan untuk melengkapi kebutuhan bahan baku tembakau bagi industri rokok yang berpusat di Pulau Jawa.

Konsep dasar dari teori circular cumulative causation adalah bahwa jika perekonomian dijalankan sepenuhnya oleh hukum pasar, maka pertumbuhan ekonomi akan berpusat di wilayahwilayah maju, sementara wilayah tertinggal cenderung tetap tertinggal. Hal ini disebabkan karena dalam hukum pasar, ekonomi digerakkan sepenuhnya oleh motif laba. Dengan demikian investor akan memilih untuk berinvestasi di wilayah maju karena kemungkinan untuk mendapatkan laba maksimum menjadi lebih besar. Wilayah maju memiliki segala yang dibutuhkan investor untuk mendapat laba maksimum seperti infrastruktur, tenaga kerja, modal, pasar (konsumen), jaringan kelembagaan, dan sebagainya yang tidak dimiliki oleh wilayah tertinggal (Jhingan, 1999). Adapun manfaat yang diterima oleh daerah tertinggal sering disebut dengan spread effect ataupun trickle down effect.

Komoditas tembakau mulai ditanam di Pulau Lombok sejak tahun 1969 namun perkembangan yang signifikan terhadap usahatani ini mulai terjadi pada akhir dekade 1980-an (Disbun NTB, 2002). Banyak studi yang menunjukkan bahwa hadirnya usahatani tembakau maupun berkembangnya pola kemitraan dalam usahatani tembakau di Pulau Lombok telah berhasil meningkatkan pendapatan, efisiensi, dan produktifitas petani sebagaimana ditunjukkan oleh studi
Nurjihadi (2011), Hamidi (2009), serta Susrusa dan Zulkifli (2009). Saat ini Pulau Lombok telah menjadi pensuplai utama kebutuhan tembakau nasional bersama Provinsi Jawa Timur dan Jawa Tengah. Untuk tembakau jenis Virginia, Pulau Lombok mensuplai lebih dari $80 \%$ kebutuhan nasional. Meski menjadi wilayah pensuplai utama kebutuhan bahan baku industri rokok, para investor industri tokok itu hingga kini tidak berkenan untuk membangun pabrik rokok di Pulau Lombok.

Hasil wawancara mendalam dengan pimpinan PT. Djarum Lombok dan PT. AOI mengungkap bahwa perusahaan rokok tidak mungkin membangun pabrik di Pulau Lombok. Hal ini disebabkan karena minimnya infrastruktur dasar yang dibutuhkan industri di Pulau Lombok, minimnya Sumber Daya Manusia (SDM) terlatih sebagai tenaga kerja, rendahnya jumlah konsumen, serta biaya transportasi input maupun output yang mahal. Kesimpulan ini dipertegas kembali melalui hasil FGD dengan seluruh stakeholder tembakau di Pulau Lombok yang terdiri dari pimpinan perusahaan-perusahaan pengepul tembakau yang beroperasi di Pulau Lombok, pimpinan asosiasi petani tembakau di Lombok, Pemerintah Daerah terkait, serta akademisi. Hasil FGD itu menegaskan bahwa untuk saat ini membangun pabrik rokok di Pulau Lombok tidaklah memungkinkan karena para investor berpendapat bahwa potensi labanya sangat kecil. Hal ini dapat dipahami dengan teori circular cumulative causation.

Salah satu poin penting dari teori circular cumulative causation adalah adanya keyakinan bahwa dalam sistem ekonomi pasar, spread effect yang diterima wilayah terbelakang dari berkembangnya industri di wilayah maju jauh lebih kecil dibanding dengan backwash effect yang diciptakannya. Agribisnis tembakau Virginia di Pulau Lombok sebagai salah satu spread effect dari berkembangnya industri rokok di Pulau Jawa memang memberikan dampak yang cukup signifikan bagi masyarakat Pulau Lombok sebagaimana ditunjukkan oleh studi Nurjihadi (2011), Susrusa dan Zulkifli (2009), dan Hamidi (2009). Namun demikian efek pencucian balik (backwash effect) yang diciptakan juga besar. Backwash effect ini dapat dilihat dalam perspektif lingkungan, sosial, ekonomi, kesehatan, dan lainnya. Salah satu indikator penilaian backwash effect ini adalah kebocoran ekonomi wilayah (economic leakages) yang umumnya terjadi karena rendahnya kemampuan menciptakan nilai tambah didalam wilayah.

Kebocoran Ekonomi Wilayah (Economic Leakages) dalam Agribisnis Tembakau Virginia Lombok

Kebocoran ekonomi wilayah mengukur seberapa besar potensi pendapatan suatu wilayah yang tidak dapat dinikmati oleh wilayah itu karena adanya aliran sumber daya ke luar wilayah tanpa melalui proses penciptaan nilai tambah ( $a d d$ value) terlebih dahulu. Untuk mengukur kebocoran ekonomi wilayah pada agribisnis tembakau Virginia Lombok, perlu diketahui seberapa besar nilai ekonomi dari tembakau Virginia tersebut jika sudah mengalami proses penciptaan nilai tambah, dalam hal ini setelah tembakau itu diolah menjadi produk rokok. Nilai ekonomi tembakau itu dihitung dengan menggunakan pendekatan harga eceran per batang rokok.

$\mathrm{TEV}=(\mathrm{P}-\mathrm{C}-\mathrm{KF}-[\mathrm{Pc}-\mathrm{T}]-\pi \mathrm{p}-\mathrm{o})(\mathrm{V} \%)(\mathrm{R})$ 


$$
\begin{aligned}
= & (800-312-100-40-100-50)(38,5 \%) \\
& (80.000 .000 .000) \\
= & (198)(38,5 \%)(80.000 .000 .000) \\
= & R p 6.098 .400 .000 .000,-
\end{aligned}
$$

Berdasarkan perhitungan diatas, maka nilai ekonomi murni tembakau virginia Lombok setelah diolah menjadi produk rokok adalah Rp.6.098.400.000.000,- (enam trilliun sembilan puluh delapan milliar empat ratus juta rupiah). Untuk mendapatkan nilai ekonomi sebesar itu, dibutuhkan kombinasi berbagai faktor produksi guna menghasilkan produk rokok seperti tenaga kerja, mesin, kertas, filter, dan sebagainya. Perhitungan ini telah menghilangkan segala unsur biaya produksi rokok, kecuali tembakau Virginia Lombok. Perhitungan diatas dibangun dari asumsi-asumsi berikut:

1. Berdasarkan hasil survey lapangan dan eksperimen terukur, didapatkan informasi bahwa harga eceran per batang rokok adalah Rp.800,-. Harga tersebut sudah termasuk biaya cukai yang dibayarkan konsumen sebesar Rp.312,- per batang rokok; biaya kertas, filter dan kemasan rokok diasumsikan Rp.100,-; keuntungan pengecer Rp.100,-; dan biaya lainnya sebesar Rp.50,--

2. $\quad$ Production cost $(\mathrm{Pc})$ pada rumus diatas sebenarnya menggambarkan fungsi himpunan dari input produksi berupa tembakau dari berbagai jenis, cengkeh, saus, biaya tenaga kerja dan iklan, namun karena dalam perhitungan ini yang dicari adalah nilai ekonomi murni dari tembakau virginia Lombok, maka elemen production cost dibatasi hanya sebagai fungsi himpunan dari tembakau virginia Lombok. Jadi, biaya produksi dalam perhitungan nilai ekonomi ini dikurangi dengan nilai kandungan tembakau Virginia dalam rokok tersebut ( [Pc-T] ).

3. Nilai [Pc-T] diasumsikan sebesar Rp 40,-. [Pc-T] ini sesungguhnya merupakan asumsi nilai biaya tenaga kerja untuk membuat satu batang rokok dan biaya iklan.

4. Nilai tembakau dalam perhitungan itu diasumsikan sebesar Rp 60,-. Hanya saja perlu diketahui bahwa nilai Rp 60,- bukanlah nilai murni tembakau virginia Lombok. nilai itu masih bercampur dengan nilai jenis tembakau lainnya beserta cengkeh dan saus.

5. Setiap batang rokok rata-rata mengandung $38,5 \%$ tembakau virginia Lombok dari total kandungan tembakau, cengkeh dan saus. Jadi, untuk mendapatkan nilai ekonomi murni tembakau virginia Lombok, hasil perhitungan nilai ekonomi tembakau secara umum harus dikalikan dengan $38,5 \%$. Prosentase ini didapatkan dari hasil perhitungan

$\mathrm{V} \%=(0,5$ gr $/ 1,3$ gr $) 100 \%$

$\mathrm{V} \%=38,5 \%$

0,5 gr merupakan kandungan tembakau Virginia per batang rokok berdasarkan keterangan informan kunci. 1,3 gr merupakan berat rata-rata tembakau dalam satu batang rokok berdasarkan hasil penimbangan di laboratorium.

6. Angka 80.000 .000 .000 (delapan puluh milliar) dalam perhitungan diatas adalah jumlah batang rokok yang dihasilkan oleh tembakau virginia Lombok dari total produksi 40.000 ton tembakau virginia setiap tahun di mana setiap batang rokok mengandung 0,5 gr tembakau virginia Lombok. 40.000 ton dibagi 0,5 gr sama dengan 80 miliar batang rokok.
Setelah mengetahui nilai ekonomi dari tembakau Virginia Lombok, selanjutnya perlu diketahui seberapa besar pendapatan wilayah pulau Lombok dari agribisnis tembakau Virginia Lombok. Pendapatan wilayah pulau Lombok ini dapat dilihat dari besarnya keuntungan usahatani, upah buruh, belanja kebutuhan agroinput di dalam wilayah Pulau Lombok dan sebagainya. Untuk mengetahui jumlah itu, diperlukan analisis usahatani tembakau Virginia Lombok. Berdasarkan data primer yang berhasil dikumpulkan selama penelitian, didapatkan hasil perhitungan analisis usahatani tembakau

\begin{tabular}{|c|c|c|}
\hline No & Komponen Pembiayaan & Jumlah (Rp) \\
\hline 1. & $\begin{array}{l}\text { Biaya Lahan } \\
\text {-Sewa lahan untuk pembibitan } \\
\text {-Sewa lahan untuk penanaman } \\
\text { - Bunga } 25 \% \\
\text { Sub Jumlah }\end{array}$ & $\begin{array}{l}160.000,- \\
8.000 .000,- \\
2.040 .000,- \\
\mathbf{1 0 . 2 0 0 . 0 0 0 , -}\end{array}$ \\
\hline 2. & $\begin{array}{l}\text { Biaya Agroinput } \\
\text { - Pembibitan } \\
\text { - Penanaman } \\
\text { - Processing pasca panen } \\
\text { - Bunga 5\% } \\
\text { Sub Jumlah }\end{array}$ & $\begin{array}{l}525.330,- \\
6.891 .000,- \\
9.434 .500,- \\
842.541,- \\
\mathbf{1 7 . 6 9 3 . 3 7 2 , -}\end{array}$ \\
\hline 3 & $\begin{array}{l}\text { Biaya Tenaga Kerja } \\
\text { - Pembibitan } \\
\text { - Penanaman } \\
\text { - Processing pasca panen } \\
\text { - Bunga } 25 \% \\
\text { Sub Jumlah }\end{array}$ & $\begin{array}{l}350.000,- \\
11.375 .000,- \\
3.380 .000,- \\
3.776 .250,- \\
\mathbf{1 8 . 8 8 1 . 2 5 0 , -}\end{array}$ \\
\hline 4. & $\begin{array}{l}\text { Biaya Pengairan } \\
\text { - Pengairan } \\
\text { - Bunga } 25 \% \\
\text { Sub Jumlah }\end{array}$ & $\begin{array}{l}600.000,- \\
150.000,- \\
750.000,-\end{array}$ \\
\hline $\begin{array}{l}5 . \\
6 .\end{array}$ & $\begin{array}{l}\text { Biaya Penyusutan dengan bunga } 25 \% \\
\text { Biaya Renovasi Oven } \\
\text { - Renovasi oven } \\
\text { - Bunga } 25 \% \\
\text { Sub Jumlah }\end{array}$ & $\begin{array}{l}2.000 .000,- \\
500.000,- \\
\mathbf{2 . 5 0 0 . 0 0 0 , -}\end{array}$ \\
\hline $\begin{array}{l}\text { Tot } \\
\text { Tot: } \\
\text { Tot: } \\
\text { R/C }\end{array}$ & $\begin{array}{l}\text { Biaya Produksi } \\
\text { penerimaan }=2.000 \times 27.000,- \\
\text { Keuntungan per musim tanam } \\
\text { Ratio }\end{array}$ & $\begin{array}{l}\text { 50.024.622,- } \\
54.000 .000,- \\
3.975 .379,- \\
1,08\end{array}$ \\
\hline
\end{tabular}
Virginia Lombok sebagai berikut:

Tabel 1. Analisis usahatani tembakau virginia Lombok untuk petani pengomprong bermitra

Sumber: Data Primer diolah (2013)

Biaya renovasi oven dimasukkan dalam struktur biaya usahatani dalam analisis diatas didasarkan pada data primer di mana $100 \%$ responden mengaku harus mengganti tungku oven hampir setiap tahun. Pasca dicabutnya subsidi Bahan Bakar Minyak (BBM) khusus untuk omprongan tembakau, pemerintah, perusahaan dan akademisi terus berupaya mencari alternatif bahan bakar yang lain. Hampir setiap tahun dilakukan ujicoba terhadap satu jenis bahan bakar yang konsekuensinya adalah oven harus dimodifikasi agar sesuai dengan bahan bakar yang digunakan. Pada tahun 2009, pemerintah daerah pernah menganggarkan untuk membantu biaya modifikasi oven pengomprong, namun karena terus terjadi perubahan dalam penggunaan bahan bakar setiap tahun, maka pemerintah menghentikan bantuan biaya modifikasi oven tersebut. Akibatnya pengomprong harus mengupayakan sendiri biaya modifikasi ovennya. Menurut pengakuan responden, setiap tahun pengomprong harus 
mengeluarkan biaya sekitar 1 juta -8 juta rupiah untuk keperluan modifikasi oven. Sebagian responden juga mengaku tidak harus memodifikasi ovennya setiap tahun, terkadang satu jenis modifikasi bisa dipakai untuk dua atau tiga kali musim tanam tembakau. Penulis mengambil nilai rataan terkecil dalam laporan penelitian ini, yaitu $\mathrm{Rp}$ 2.000.000,-, meskipun pada faktanya angka rataan untuk keperluan modifikasi oven sebenarnya sangat mungkin lebih besar dari itu.

Berdasarkan data diatas, didapatkan informasi bahwa nilai keuntungan petani pengomprong yang bermitra dengan perusahaan rata-rata hanya sebesar Rp 3.975.379,-- per hektar per musim tanam. Rata-rata hasil produksi tembakau Virginia Lombok per musim tanam adalah 40.000 ton, sementara hasil produksi rata-rata per hektar adalah 2 ton. Dengan demikian, total luas areal tanam tembakau rata-rata adalah

$$
\begin{aligned}
\mathrm{TF} & =\mathrm{TPa} / \mathrm{TP} \\
& =40.000 \text { ton } / 2 \text { ton } \\
& =20.000 \mathrm{ha}
\end{aligned}
$$

Dengan demikian, maka total pendapatan wilayah Pulau Lombok dari keuntungan usahatani tembakau Virginia adalah:

$$
\begin{aligned}
\mathrm{RI} \pi & =\pi \times \mathrm{TF} \\
& =\operatorname{Rp} 3.975 .379 \times 20.000 \text { ha } \\
& =\operatorname{Rp} 79.507 .580 .000,-
\end{aligned}
$$

Selain keuntungan usahatani, pendapatan wilayah pulau Lombok dari agribisnis tembakau juga didapat dari upah buruh yang bekerja pada usahatani tembakau tersebut. Menurut data dari Dinas Perkebunan Provinsi NTB (2012), pada tahun 2011 industri pertembakauan telah berhasil menyerap 140.000 tenaga kerja selama lima bulan musim tanam di Pulau Lombok. Angka itu diluar jumlah petani tembakau yang telah dihitung sebelumnya. Jika rata-rata total penyerapan buruh sebesar 140.000 per tahun, maka berdasarkan data analisis usahatani diatas, dapat diketahui total pendapatan wilayah dari upah buruh (labor price) dalam pelaksanaan agribisnis tembakau virginia di Pulau Lombok adalah:

$$
\begin{aligned}
\text { RIL } & =\mathrm{LC} \times \mathrm{TF} \\
& =\mathrm{Rp} 15.105 .000 \times 20.000 \mathrm{ha} \\
& =\operatorname{Rp} 302.100 .000 .000
\end{aligned}
$$

LC adalah labor price yang merupakan total biaya yang dikeluarkan oleh petani tembakau untuk membayar upah buruh dalam usahatani mereka. Dalam tabel 1 diatas, total upah buruh diketahui sebesar Rp 15.105.000 per hektar tanaman tembakau. Dengan demikian, secara keseluruhan pendapatan wilayah Pulau Lombok dari upah buruh mencapai Rp 302.100.000.000 (tiga ratus dua miliar serratus juta rupiah). Selain itu, pendapatan masyarakat Pulau Lombok dari agribisnis tembakau Virginia juga didapatkan dari biaya sewa lahan yang dibayarkan petani kepada pemilik lahan. Jika lahan itu adalah lahan milik petani sehingga petani tidak perlu menyewanya maka petani tersebut akan mendapatkan nilai laba yang lebih besar sehingga penggunaan lahan oleh dirinya sendiri tetap terhitung sebagai sewa lahan dan menjadi pendapatan wilayah. Total pendapatan wilayah dari sewa lahan adalah:

RILR $=$ LR $\times$ TF

$$
\begin{aligned}
& =\operatorname{Rp} 8.160 .000,-x 20.000 \text { ha } \\
& =\operatorname{Rp~163.200.000.000,-~}
\end{aligned}
$$

Total pendapatan wilayah yang diterima oleh seluruh tuan tanah dalam agribisnis tembakau virginia di Pulau Lombok adalah $\mathrm{Rp}$ 163.200.000.000,- (seratus enam puluh tiga milliar dua ratus juta rupiah).

Pendapatan wilayah yang didapat oleh Pulau Lombok juga datang dari biaya bunga dan penyusutan. Dalam usahataninya, petani hanya mendapat bantuan agroinput berupa pupuk dan pestisida dari perusahaan mitra, sementara kebutuhan produksi yang lain disediakan sendiri oleh petani. Umumnya petani menggunakan uang pinjaman yang didapat dari lembabaga atau perorangan penyedia jasa peminjaman informal dengan bunga yang sangat tinggi. Berdasarkan hasil penelitian, diasumsikan bahwa bunga rata-rata yang dibayarkan petani untuk setiap modal yang dipinjamnya adalah $25 \%$. Adapun nilai penyusutan sudah dimasukkan dalam nilai bunga $25 \%$ tersebut. Hal ini dilakukan karena nilai penyusutan dalam agribisnis ini tidaklah besar mengingat sebagian biaya penyusutan yang seharusnya dihitung sebagai nilai susut dihitung sebagai biaya pada pos pembiayaan lain. Maka nilai pendapatan wilayah dari bunga pinjaman dan penyusutan adalah:

$$
\begin{aligned}
& \mathrm{RIi}=(\mathrm{iLR}+\mathrm{iLP}+\mathrm{iIr}+\mathrm{iSs}+\mathrm{iRo})(\mathrm{TF}) \\
& =(\operatorname{Rp} 2.040 .000,-+\operatorname{Rp} 3.776 .250+\operatorname{Rp~150.000,-+} \\
& \text { Rp 40.625,- + Rp.500.000,-) (20.000 ha) } \\
& =\operatorname{Rp} 130.137 .500 .000,-
\end{aligned}
$$

Bunga pinjaman untuk keperluan agroinput dalam perhitungan di atas tidak dimasukkan mengingat kebutuhan agroinput itu disediakan oleh perusahaan dalam bentuk kredit yang bunganya harus dibayarkan petani ke perusahaan juga. Kondisi itu membuat bunga pinjaman agroinput tidak terhitung sebagai pendapatan wilayah Pulau Lombok. Total pendapatan wilayah Pulau Lombok dari bunga pinjaman dan penyusutan pada agribisnis tembakau virginia Lombok adalah Rp.130.137.500.000,- (seratus tiga puluh milliar seratus tiga puluh tujuh juta lima ratus ribu rupiah).

Biaya pengairan adalah salah satu sumber pendapatan wilayah Pulau Lombok dari agribisnis tembakau Virginia. Tanaman tembakau menghendaki kondisi iklim yang kiring namun lembab. Oleh karenanya tanaman tembakau biasanya ditanam pada musim kemarau. Meski menghendaki iklim kering, tnaaman tembakau membutuhkan tanah yang terjaga kelembabannya sehingga diperlukan pengairan dalam jumlah yang cukup, tidak boleh lebih dan tidak boleh kurang. Hal itu membuat biaya pengairan pada usahatani tembakau menjadi lebih besar jika dibanding dengan biaya pengairan pada usahatani untuk komoditas lain, oleh karenanya pos pembiayaan untuk keperluan pengairan dalam analisis usahatani tembakau virginia Lombok memperhitungkan biaya pengairan sebagai pos pembiayaan tersendiri.

$$
\begin{aligned}
\text { RIIr } & =\operatorname{Ir} x \text { TF } \\
& =\operatorname{Rp} 600.000,- \text { x } 20.000 \text { ha } \\
& =\operatorname{Rp} 12.000 .000 .000,-
\end{aligned}
$$


Total pendapatan wilayah dari biaya pengairan untuk keseluruhan areal tanam tembakau virginia di Pulau Lombok adalah RP 12.000.000.000,- (dua belas milliar rupiah).

Biaya renovasi oven juga menjadi salah satu sumber pendapatan wilayah Pulau Lombok dari berkembangnya agribisnis tembakau Virginia. Hal itu karena petani rutin melakukan renovasi oven hampir setiap tahun untuk menyesuaikan oven dengan teknologi bahan bakar yang baru serta memperbaiki oven dari kerusakan setelah tidak terpakai selama musim padi. Sebagai alat produksi yang merupakan biaya tetap, biaya oven seharusnya dihitung nilai penyusutannya, namun hal itu tidak dilakukan karena adanya fakta bahwa petani (pengomprong) melakukan renovasi oven hampir setiap tahun dengan biaya yang bervariasi. Hasil penelitian menunjukkan bahwa biaya renovasi oven rata-rata adalah $\mathrm{Rp} 2.000 .000$,- per oven. Bahan dan alat yang digunakan selama renovasi diperoleh dari komponen masyarakat lainnya (pengusaha dan pengrajin) yang ada di Pulau Lombok. Dengan demikian, biaya renovasi oven dihitung juga sebagai pendapatan wilayah. Pendapatan wilayah Pulau Lombok dari biaya renovasi oven adalah:

$$
\begin{aligned}
\text { RIRo } & =\operatorname{Rox} \text { TF } \\
& =\operatorname{Rp} 2.000 .000,-\times 20.000 \text { ha } \\
& =\operatorname{Rp} 40.000 .000 .000,-
\end{aligned}
$$

Jadi, total pendapatan wilayah Pulau Lombok dari biaya renovasi oven pada agribisnis tembakau virginia Lombok adalah Rp 40.000.000.000,- (empat puluh milliar rupiah).

Selain pendapatan yang diterima oleh masyarakat setempat, baik dalam bentuk laba usahatani, upah, bunga, sewa lahan, dan sebagainya, penerimaan pemerintah daerah juga termasuk sebagai pendapatan wilayah. Pemerintah daerah dalam agribisnis tembakau virginia Lombok setidaknya berasal dari dua sumber, yakni sumbangan suka relah (retribusi daerah) yang dibayarkan langsung ke pemerintah daerah oleh perusahaan pertembakauan yang beroperasi di Pulau Lombok serta Dana Bagi Hasil Cukai Tembakau (DBHCT) yang di transfer dari pemerintah pusat ke pemerintah daerah.

Berdasarkan hasil penelitian, didapatkan informasi bahwa nilai sumbangan dari perusahaa pertembakaua yang ada di Pulau Lombok terhadap pemerintah daerah adalah Rp 100,- untuk setiap kilogram tembakau kering yang dibeli perusahaan dari petani. Dengan total produksi tembakau rata rata 40.000 ton setiap tahun, maka total penerimaan pemerintah daerah dari sumbangan suka rela (retribusi) itu adalah:

$$
\begin{aligned}
\text { RIGS } & =\text { SR } x \text { TP } \\
& =\operatorname{Rp} 100,-x 40.000 .000 \mathrm{Kg} \\
& =\operatorname{Rp} 4.000 .000 .000,-
\end{aligned}
$$

Total penerimaan pemerintah daerah dari retribusi sebesar Rp.4.000.000.000,- (empat milliar rupiah) itu dibagi dua oleh pemerintah provinsi dan pemerintah kabupaten tempat dilakukannya penanaman tembakau oleh petani dimana pemerintah provinsi mendapat $50 \%$ dan pemerintah kabupaten juga mendapat 50\%.

Selain dari sumbangan sukarela perusahaan (retribusi) kepada pemerintah daerah, penerimaan pemerintah daerah dari berkembangnya agribisnis tembakau ini juga didapatkan dari

\begin{tabular}{|c|c|c|c|c|}
\hline \multirow{2}{*}{ No } & \multirow{2}{*}{$\begin{array}{c}\text { Pem. } \\
\text { Daerah }\end{array}$} & \multicolumn{3}{|c|}{ DBH CT (miliar Rp) } \\
\hline & & 2010 & 2011 & 2012 \\
\hline 1 & $\begin{array}{l}\text { Provinsi } \\
\text { NTB }\end{array}$ & $32.814,8$ & $39.477,2$ & $\begin{array}{r}56.169 .155 \\
012\end{array}$ \\
\hline 2 & $\begin{array}{l}\text { Kab. } \\
\text { Bima }\end{array}$ & $5.628,7$ & $6.643,2$ & $8.219,3$ \\
\hline 3 & $\begin{array}{l}\text { Kab. } \\
\text { Dompu }\end{array}$ & $2.850,0$ & $3.438,2$ & $5.025,2$ \\
\hline 4 & $\begin{array}{l}\text { Kab. } \\
\text { Lombok } \\
\text { Barat }\end{array}$ & $8.071,7$ & $10.170,6$ & $13.299,8$ \\
\hline 5 & $\begin{array}{l}\text { Kab. } \\
\text { Lombok } \\
\text { Tengah }\end{array}$ & $10.892,4$ & $18.084,9$ & $24.769,4$ \\
\hline 6 & $\begin{array}{l}\text { Kab. } \\
\text { Lombok } \\
\text { Timur }\end{array}$ & $32.860,7$ & $35.551,3$ & $50.122,8$ \\
\hline 7 & $\begin{array}{l}\text { Kab. } \\
\text { Sumbawa }\end{array}$ & $5.552,0$ & $6.651,7$ & $8.731,0$ \\
\hline 8 & $\begin{array}{l}\text { Kota } \\
\text { Mataram }\end{array}$ & $4.859,6$ & $1.436,5$ & $6.091,8$ \\
\hline 9 & $\begin{array}{l}\text { Kota } \\
\text { Bima }\end{array}$ & $1.738,1$ & $2.591,4$ & $4.213,1$ \\
\hline 10 & $\begin{array}{l}\text { Kab } \\
\text { Sumbawa } \\
\text { Barat }\end{array}$ & $1.323,7$ & $3.098,1$ & $4.597,2$ \\
\hline 11 & $\begin{array}{l}\text { Kab. } \\
\text { Lombok } \\
\text { Utara }\end{array}$ & $2.791,2$ & $4.447,6$ & $5.991,8$ \\
\hline & Jumlah & $109.382,8$ & $131.590,6$ & $187.230,5$ \\
\hline
\end{tabular}
Dana Bagi Hasil Cukai Tembakau (DBHCT) yang mulai diberikan pemerintah pusat sejak tahun 2010. Berikut adalah tabel perkembangan penerimaan pemerintah daerah dari cukai tembakau:

Tabel 2. DBHCT yang diterima pemerintah daerah se Provinsi NTB

Sumber: APBN Republik Indonesia dalam Sosialisasi Kementan RI (2013)

Data diatas merupakan data time series selama tiga tahun terakhir. Analisis dalam penelitian ini menggunakan data terbaru yakni data tahun 2012 di mana pada tahun tersebut seluruh pemerintah daerah yang ada di Provinsi NTB menerima total Rp.187.230.516.7,-, dari jumlah itu yang menjadi pendapatan di wilayah Pulau Lombok adalah:

$$
\begin{aligned}
\text { RIGC }= & \text { CProv }+ \text { CLotim }+ \text { CLoteng }+ \text { CLobar + CKLU + } \\
= & \text { Rp. } 56.169 .155 .012,-+ \text { Rp.50.122.791.177,- + } \\
& \text { Rp. } 24.769 .415 .506,-+ \text { Rp.13.299.825.306,- + } \\
& \text { Rp.5.991.786.585,- + Rp.6.091.786.585,- } \\
= & \text { Rp } 156.444 .760 .171,-
\end{aligned}
$$

Kabupaten/kota yang berada di luar Pulau Lombok, tidak dihitung dalam perhitungan di atas karena memang yang dicari adalah pendapatan wilayah Pulau Lombok. Pendapatan pemerintah provinsi tetap dihitung sebagai pendapatan wilayah Pulau Lombok karena ibu kota pemerintah daerah provinsi ada di Pulau Lombok. Artinya, pendapatan pemerintah provinsi itu juga menjadi pendapatan wilayah Pulau Lombok. Adapun total pendapatan wilayah Pulau 
Lombok adalah Rp 156.444.760.171,- (seratus lima puluh enam milliar empat ratus empat puluh empat juta tujuh ratus enam puluh ribu seratus tujuh puluh satu rupiah).

Berdasarkan perhitungan pendapatan pemerintah dari retribusi dan cukai diatas, maka didapatkan total pendapatan pemerintah dari adanya agribisnis tembakau ini adalah:

$$
\begin{aligned}
\text { GIt } & =\text { RIGS + RIGC } \\
& =\text { Rp 4.000.000.000,- + Rp 156.444.760.171,- } \\
& =\text { Rp 160.444.760.171,- }
\end{aligned}
$$

Pendapatan wilayah Pulau Lombok dari penerimaan pemerintah dalam agribisnis tembakau virginia adalah $\mathrm{Rp}$ 160.444.760.171,-- (seratus enam puluh milliar empat ratus empat puluh empat juta tujuh ratus enam puluh ribu seratus tujuh puluh satu rupiah).

Dengan demikian, maka secara keseluruhan total pendapatan wilayah Pulau Lombok dari agribisnis tembakau Virginia adalah:

$$
\begin{aligned}
& \text { RIt }=\mathrm{RI} \pi+\mathrm{RIL}+\mathrm{RILR}+\mathrm{RIi}+\mathrm{RIIr}+\mathrm{RIRo}+\mathrm{GIt} \\
& =\text { Rp.79.507.580.000,- + Rp.302.100.000.000,- + } \\
& \text { Rp.163.200.000.000,- + Rp.130.137.500.000,- + } \\
& \text { Rp.12.000.000.000,- + Rp.40.000.000.000,- + } \\
& \text { Rp.160.444.760.171,- } \\
& =\operatorname{Rp} 887.389 .840 .171,-
\end{aligned}
$$

Berdasarkan perhitungan-perhitungan diatas, maka didapatkan total pendapatan wilayah Pulau Lombok dari adanya agribisnis tembakau virginia adalah $\mathrm{Rp}$ 887.389.840.171,- (delapan ratus delapan puluh tujuh milliar tiga ratus delapan puluh sembilan juta delapan ratus empat puluh ribu seratus tujuh puluh satu rupiah).

Kebocoran ekonomi wilayah atau yang dapat juga dikatakan sebagai potensi nilai tambah wilayah yang hilang dari agribisnis tembakau Virginia Lombok dapat diketahui dengan menghitung selisih antara nilai ekonomi tembakau virginia Lombok dengan total pendapatan wilayah yang dapat diciptakan oleh agribisnis tembakau virginia Lombok tersebut. Potensi nilai tambah yang hilang berarti besarnya nilai tambah yang tidak dinikmati oleh masyarakat Pulau Lombok atau dinikmati oleh masyarakat luar Pulau Lombok. Hal ini umumnya terjadi karena tidak adanya aktifitas pengolahan hasil di dalam suatu wilayah, dalam hal ini adalah wilayah Pulau Lombok.

$$
\begin{aligned}
\mathrm{EL} & =\mathrm{TEV}-\mathrm{RIt} \\
& =(\operatorname{Rp} 6.098 .400 .000 .000,-)-(\operatorname{Rp} 887.389 .840 .171,-) \\
& =\operatorname{Rp} 5.211 .010 .159 .829,-
\end{aligned}
$$

Perhitungan diatas menunjukkan bahwa total kebocoran ekonomi wilayah dalam agribisnis tembakau Virginia di Pulau Lombok itu mencapai Rp 5.211.010.159.829,-- (lima trilliun dua ratus sebelas milliar sepuluh juta seratus lima puluh sembilan ribu delapan ratus dua puluh sembilan rupiah). Nilai ini termasuk sangat besar jika dibanding dengan total pendapatan wilayah yang diterima oleh masyarakat Pulau Lombok. Artinya masyarakat di wilayah Pulau Lombok itu lebih banyak kehilangan nilai tambah daripada menerima pendapatan wilayah dari agribisnis tembakau virginia Lombok. Hasil ini identik dengan temuan Lewin et al (2013) yang meneliti dinamika multiplier effect antar wilayah core-periphery di Portland dan Oregon dimana hasil penelitiannya menunjukkan bahwa multiplier effect dari wilayah penunjang (periphery) ke wilayah inti (core) lebih besar daripada multiplier effect dari wilayah core ke wilayah periphery.

\section{Kesimpulan}

Penelitian ini menegaskan kembali tesis Gunar Myrdal mengenai Circular Cumulative Causation Theory. Menggunakan dinamika agribisnis tembakau Virginia Lombok sebagai studi kasus, penelitian ini berhasil membuktikan bahwa hukum pasar bekerja untuk memajukan wilayah yang sudah maju dan cenderung membuat wilayah terbelakang tetap tertinggal. Hal ini terjadi karena lebih besarnya bachwash effect daripada spread effect dalam agribisnis tembakau virginia Lombok yang dibuktikan dengan besarnya nilai kebocoran ekonomi wilayah (economic leakages) pada agribisnis itu dibanding dengan besarnya pendapatan wilayah yang mampu diciptakannya. Adapun total kebocoran ekonomi wilayah dalam agribisnis tembakau virginia Lombok itu mencapai Rp 5.211.010.159.829,- (lima trilliun dua ratus sebelas milliar sepuluh juta seratus lima puluh sembilan ribu delapan ratus dua puluh sembilan rupiah) sementara pendapatan wilayah yang dihasilkannya mencapai Rp 887.389.840.171,- (delapan ratus delapan puluh tujuh milliar tiga ratus delapan puluh sembilan juta delapan ratus empat puluh ribu seratus tujuh puluh satu rupiah).

\section{Referensi}

[Disbun NTB] Dinas Perkebunan Provinsi NTB. 2002. Makalah Kebijakan Pengembangan TembakauVirginia Lombok Melalui Program Intensifikasi Tembaku Virginia Lombok. Mataram (ID): Disbun NTB

[Kementan RI] Kementerian Pertanian Republik Indonesia. 2013. Kebijakan Pengembangan Tembakau Nasional. Mataram (ID): Sosialisasi Program Intensifikasi Tembakau Virginia Lombok

[Pusdatin Kementan] Pusat Data dan Sistem Informasi Pertanian Kementerian Pertanian RI. 2014. Outlook Komoditi Tembakau. Kementerian Pertanian RI Jakarta

[TCSC-IAKMI] Tobacco Control Support Center - Ikatan Ahli Kesehatan Masyarakat Indonesia. 2008. Petani Tembakau Indonesia. Jakarta(ID). TCSC-IAKMI

Anonim. 2016. Kinerja H.M.Sampoerna (HMSP): Laba Rokok Menggunung, Saham Melambung. Retrieved from http://m.bisnis.com/market/read/kinerjasampoerna

Bendavid-val, A. 1991. Regional and Local Economic Analysis for Practicioners Fourth Edition. London (UK). Praeger

Capello, R. 2007. Regional Economics. New York (US) Routledege

Hamidi, Hirwan. 2009. Dampak Kemitraan Terhadap Efisiensi Usahatani Tembakau Virginia di Pulau Lombok Provinsi NTB. Agroteksos. Vol. 19/1-2. pp. 42-47.

Jhingan, M.L. 1999. Ekonomi Pembangunan dan Perencanaan. Jakarta (ID). Raja Grafindo Persada 
Lewin P, Weber B, and Holland D. 2013. Core-Periphery Dynamics in the Portland, Oregon Region: 1982-2006. The Annal of Regional Science. Vol. 51. pp.411-433.

Myrdal, Gunar. 1964. Economic Theory and Underdeveloped Regions. London (UK). Allen and Unwin.

Nurjihadi, Muhammad. 2016. The Vicious Circle of Poverty in the Rural Society, Case Study of Tobacco Farmers in the Rural area of Lombok Island..Journal of Sodality Vol.4/2. Pp.120-127.

Rustiadi E, Saefulhakim S, dan Panuju D.R. 2011. Perencanaan dan Pengembangan Wilayah. Bogor (ID). Cresspen Press

Susrusa K.B, Zulkifli. 2009. Efektifitas Kemitraan Pada usahatani Tembakau Virginia di Kabupaten Lombok Timur. Jurnal SOCA. Vol. 09/01. pp. 73-80.

Tarigan, R. 2002. Perencanaan Pembangunan Wilayah. Jakarta (ID). Depdiknas 